\title{
A Study on Ownership Structure and Financial Performance of Listed Beverage Food and Tobacco Companies in Sri Lanka
}

\author{
Saseela Balagobei (Corresponding author) \\ PhD Scholar, Faculty of Post Graduate Studies \\ University of Jaffna, Sri Lanka \\ E-mail: saseelas@yahoo.com \\ Thirunavukkarasu Velnampy \\ Professor in Accounting, Faculty of Management Studies and Commerce \\ University of Jaffna, Sri Lanka
}

Received: July 9, 2017

Accepted: July 25, 2017

Published: October 10, 2017

doi:10.5296/ijafr.v7i2.11518

URL: https://doi.org/10.5296/ijafr.v7i2.11518

\begin{abstract}
The relevant literature suggests that ownership structure is one of the main corporate governance mechanisms influencing the scope of financial performance. The aim of this study is to investigate the relationship between ownership structure and financial performance of listed beverage food and tobacco companies for the period of 2010-2015. This study also examines the impact of ownership structure on financial performance. The sample consists of 10 listed beverage food and tobacco companies in Sri Lanka. In this study, data was collected from secondary sources and hypotheses are examined by using Pearson's correlation and regression analysis. The results reveal that ownership concentration and foreign ownership structure are positively correlated with financial performance of listed beverage food and tobacco companies while institutional ownership structure isn't significantly correlated with financial performance. It is also found that there is a significant impact of foreign ownership structure on financial performance. Higher the foreign ownership structure in listed beverage food and tobacco companies, the higher the financial performance which is preferable for the shareholders and it improves the wealth of companies.
\end{abstract}


Keywords: corporate governance, financial performance, institutional ownership, ownership concentration

JEL: G34

\section{Introduction}

Corporate governance has become an issue of global significance. Ownership structure is an important internal mechanism of corporate governance. It is defined by the distribution of equity with regard to votes and capital as well as the identity of the equity owners. These structures are of major importance in corporate governance because they determine the incentives of managers and thereby the economic efficiency of the corporations they manage (Jensen and Meckling, 1976). The term 'ownership structure' has two widely applied dimensions: ownership concentration and owner identity. Ownership concentration measures the degree of concentration of voting right in listed corporations, it is measured by the voting right of the largest shareholders. Owner identity is based on the type of the largest shareholder.

Financial performance is a subjective evaluation of how well a firm can use assets from its primary mode of business and generate revenues. The term is also used as a general measure of a firm's general financial health over a given period of time, and can be used to compare similar firms within the same industry or to compare industries or sectors in aggregate (Fauzi, 2007).

The relationship between ownership structure and corporate performance are assumed to exist, because ownership concentration and owner identity influence the incentives of each party within the firm, and thus influence the firm's ability to solve agency problems (Chen, 2012). However, the relationship between ownership structure and firm performance remains blurred in previous studies. To illustrate with the effect of ownership concentration on the corporate performance, the effect has contradicting conclusions from former studies. While Shleifer and Vishny (1986) and Ødegaard (2003) found positive effect of high concentration; Hindley (1970), and Fama and Jensen (1983) found the effect to be negative. Furthermore studies related to owner identities and firm performance also have contradicting conclusions.

Demsetz and Lehn (1985) mentioned that ownership structure is about the concentration of shares held by shareholders; the researchers made a distinction between top five and top twenty shareholders. Ownership identity argues about "who are the owners". Ownership identity considers two types of ownership, insiders and outsiders. Insiders are shareholders who work or have worked at the company; outsiders are shareholders who have never been employees of the firm (Bauguess et al., 2009). There are different types of owners for listed firms: institutional ownership, foreign ownership and government ownership.

In Sri Lanka, apart from weak regulatory and institutional frameworks, increasing oil prices, overvalued exchange rates and rising inflation have been growing macroeconomic problems that were further worsened by the Tsunami and global finance crisis which in turn affected the performance of firms. Remarkably, despite all these setbacks, the stock market in Sri Lanka has generally continued to perform well. This situation offers a good opportunity for investigating the relationship between the ownership Structure and financial performance of listed beverage food and tobacco companies in Sri Lanka during the period of 2010-2015. 


\section{Mll Macrothink}

International Journal of Accounting and Financial Reporting

ISSN 2162-3082

2017, Vol. 7, No. 2

\subsection{Statement of the Problem}

Ownership structure, as a mechanism in corporate governance to facilitate increased efficiency of a firm, has been believed to effect firm performance for many years. Stock markets are widely viewed as important, if not essential, for the functioning of modern capitalist economies. Ownership concentration as a direct control indicator of the company, provide investors with the ability and motivation to control and monitor the management. Previous studies find mixed results for ownership concentration and company financial performance.

Agency theory suggests that concentrated ownership will result in better monitoring of the management which makes ownership an important element in corporate governance. This, in turn improves company performance. Some previous studies also reveal that there is a significant relation between ownership concentration and performance (Shleifer and Vishny, 1997; Mang'unyi, 2011; Pivovarsky, 2003; Sanda, Mikailu and Garba, 2005; Joh, 2002; Xu and Wang, 1997). But some other previous studies disclose an absence of relation between ownership concentration and performance (Demsetz and Lehn, 1985; Shan and McIver, 2011; Sánchez-Ballesta and García-Meca, 2007; Najjar, 2012; Tsegba and Ezi-Herbert, 2011). The relationship between ownership concentration and firm performance is still inconclusive.

The connection between ownership structure and performance is an ongoing debate in the corporate finance literature. Whilst authors like Berle and Means (2002) suggests an inverse correlation between shareholdings and firm performance, Demsetz (2001) indicated that the ownership structure of a corporation should be thought of as an endogenous outcome of decisions that reflect the influence of shareholders and of trading on the market for shares.

A huge gap exists in literature on the association between ownership structure and a firm performance. This study therefore investigates the pattern and variation of ownership structure of listed companies and to document empirically the relationship between financial performance and corporate governance through ownership structure.

Thus the research question is formulated as "Whether there is any relationship between ownership structure and financial performance of listed beverage food and tobacco companies in Sri Lanka?

\subsection{Objectives of the Study}

The primary objective of this study is to identify the relationship between the ownership Structure and financial performance of listed beverage food and tobacco companies in Sri Lanka.

The secondary objectives are as follows,

- To investigate the impact of ownership Structure on financial performance.

- To suggest the recommendation to boost the financial performance through adapting a better strategic framework of ownership structure. 


\section{Literature Review}

In recent years research has given increasing attention to the issue of corporate ownership structure and its impact on the financial performance of firms. There are various studies related to the corporate ownership structure and performance.

Soufeljil, Sghaier, Kheireddine and Mighri (2016) revealed the existence of a positive impact and statistically significant concentration of ownership, on the performance of the company measured by the ROA. Also, the results show the existence of a positive effect of the ownership of institutional investors on the performance of the company. Foreign investors have a positive impact and statistically significant effect on the performance of the listed company.

Herdjiono and Sari (2017) indicated that the size of the board of directors has a positive effect on financial performance, while the size of the audit committee, institutional ownership and managerial ownership has no effect on the financial performance. While on the simultaneously testing, it showed that the size of the board of directors, audit committee size, institutional ownership and managerial ownership influence the financial performance

Earnhart and Lizal (2006) analyzed the effects of ownership structure on corporate environmental performance and examines the relationship between financial performance and environmental performance in a transition economy. This study revealed that increased state ownership actually improves environmental performance relative to all other ownership types, even though the state is more likely to have retained ownership in high-polluting industries.

Abu Haija and Alrabba (2017) showed a positive relationship among managerial, institutional and family ownership and financial performance, while there is no significant relationship between foreign ownership and firm's financial performance.

Shleifer and Vishny (1997) revealed that since the concentrated ownership provide the objectives of value maximizing and sufficient control rights over the company, it can monitor the management effectively and reduce the agency costs resulting in improved firm performance. Mang'unyi (2011) investigated the effects of ownership structure over institution management and performance in the sample of some selected banks operand in Kenya and revealed that there is a significant relationship between ownership structure and financial performance. The researcher defends that banks that have foreign investor, in comparison with banks that have domestic investor, display a better performance.

Warrad et al (2013) examined the relationship between ownership concentration and business performance of nonfinancial businesses that are listed on the stock exchange of Jordan between the years 1994 and 2005. In this study, two different group assessment criteria are determined as for accounting and market. According to accounting criterions it is concluded that ownership structure doesn't have a significant effect on business performance, however according to market criterions it is determined that ownership structure effects business performance significantly. 


\section{Macrothink}

International Journal of Accounting and Financial Reporting

ISSN 2162-3082

2017, Vol. 7, No. 2

Welch (2003) considered the multi dimensionality of ownership structure and found that institutional ownership and managerial ownership are part of an endogenous system that should be considered when performing other studies concerning the effect of ownership on performance. Their results suggested that higher proportions of institutional ownership resulted in better company performance.

Gürbüz, Aybars and Kutlu (2010) analyze 164 firms from the Istanbul Stock Exchange and demonstrate a positive relationship between corporate governance and institutional ownership on firm financial performance. Using 1,914 US companies, Clay (2001) finds a significant positive relationship between company performance and institutional ownership percentage, where a $1 \%$ increase in institutional ownership leads to $0.75 \%$ increase in company financial performance. But Loderer and Martin (1997) found that there is no significant relationship between institutional ownership and firm performance.

Douma, George and Kabir (2006) examined the impact of foreign ownership on corporate performance in India. They point out that foreign ownership has a positive impact on corporate performance because foreigners have sufficient corporate governance in the internal system of the companies. Ongore (2011) conducted a study in Kenya to test the impact of several ownership categories on corporate performance. He found that foreign ownership has positive and significant relationship with corporate performance. Furthermore, he argued that foreign investors can help to enhance management system and easy access to massive resources.

Lee (2008) considers the Korean context and explains that due to foreign ownership, some companies have more superior corporate governance mechanisms than local firms, suggesting foreign owned companies may have higher financial performance. Huang and Shiu (2009) find that foreign ownership is significantly and positively related with firm research and development expenses and contemporaneous and subsequent firm performance. Khanna and Palepu (2000) argue that foreign ownership performs an effective monitoring function of the firm management. Foreign ownership often contributes to managerial and organizational capabilities by providing organizational resources and knowledge in addition to financial capital.

Most of the studies are concerned with the Western countries. But the best of the researcher's knowledge restricted of the ownership structure and financial performance study focuses on listed beverage food and tobacco companies in Sri Lanka where neither have been found or published. Therefore this study is an endeavor to investigate the relationship between the ownership Structure and financial performance of listed beverage food and tobacco companies in Sri Lanka.

Based on the literature review the following hypotheses were formulated for the study.

$\mathrm{H}_{1}$ : There is a significant relationship between the ownership concentration and financial performance.

$\mathrm{H}_{2}$ : There is a significant relationship between the institutional ownership and financial performance 


\section{Macrothink}

International Journal of Accounting and Financial Reporting

ISSN 2162-3082

2017, Vol. 7, No. 2

$\mathrm{H}_{3}$ : There is a significant relationship between the foreign ownership and financial performance

$\mathrm{H}_{4}$ : There is a significant impact of the ownership concentration on financial performance.

$\mathrm{H}_{5}$ : There is a significant impact of the institutional ownership on financial performance

$\mathrm{H}_{6}$ : There is a significant impact of the foreign ownership on financial performance

\section{Conceptual Framework}

Based on the literature survey and problem statement of the study, the following conceptual frame work has been constructed to show the relationship between the ownership Structure and financial performance of listed beverage food and tobacco companies in Sri Lanka.

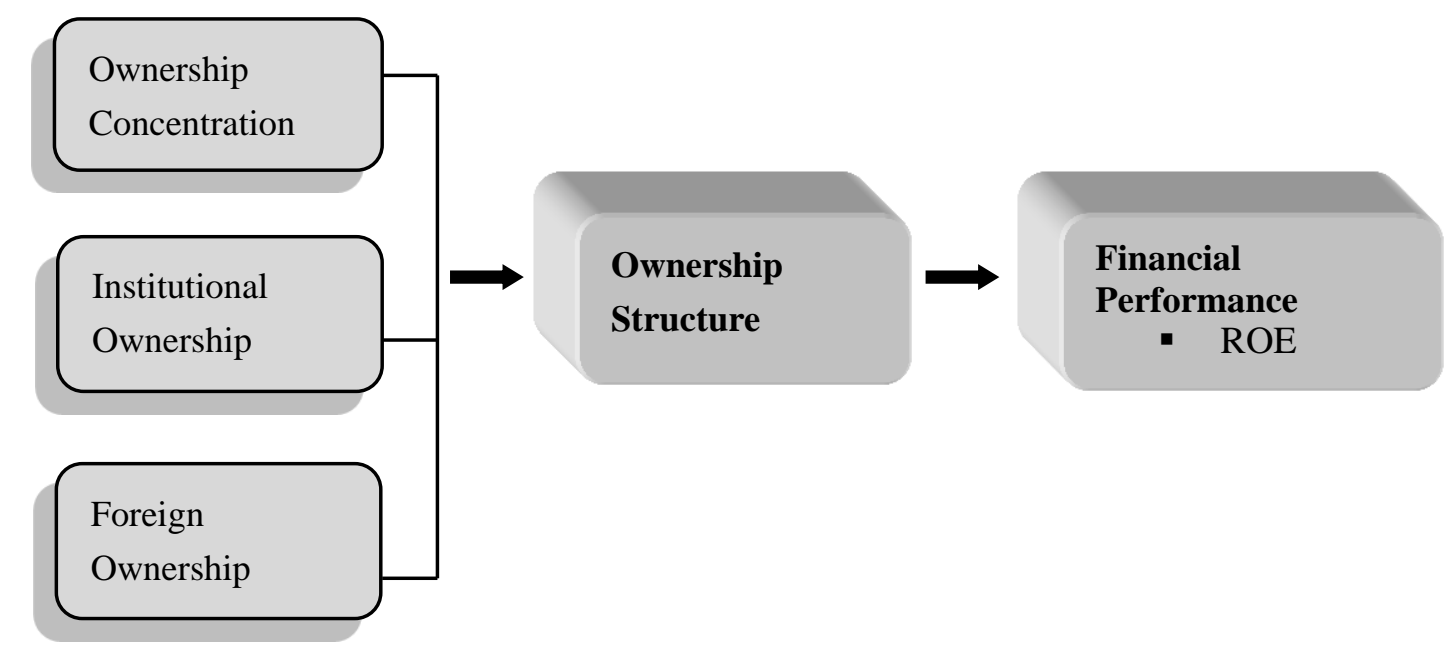

Figure 1. Conceptual Framework

Source: Developed by researcher

\section{Methodology}

Research methodology focuses on the research process a kind of tools and procedures to be used. It describes research design, research approach, sampling procedure, data sources, instrumentation, and mode of analysis.

\subsection{Data Collection}

Data was collected from secondary sources, mainly from annual report of listed companies, which were published by Colombo Stock Exchange (CSE) in Sri Lanka for the period of 2010-2015. Further, scholarly articles from academic journals, relevant text books and the internet search engines were also used.

\subsection{Sampling Design}

The sample of this study is drawn from firms listed in the CSE during the period of 2010 to 2015. The CSE is the organization responsible for the operation of the stock market in Sri 


\section{1l Macrothink}

International Journal of Accounting and Financial Reporting

ISSN 2162-3082

2017, Vol. 7, No. 2

Lanka. It has 295 companies representing 20 business sectors in 2015. In this study, Sri Lankan beverage food and tobacco companies listed in CSE were selected to examine the relationship between the ownership and financial performance. Out of twenty three beverage food and tobacco companies only ten companies are included in the sample which represents $43 \%$ of the beverage food and tobacco companies listed in the CSE. This sample selection was based on random sampling method to carry out the research.

\subsection{Measurement of the Study}

The following methods chosen to derive the results in this study are based on data analysis.

- Ownership concentration- Number of shares owned by major shareholders / Total number of the shares

- Institutional ownership - Number of shares owned by institution / Total number of the shares

- Foreign ownership - Number of shares owned by foreigners / Total number of the shares

- $\quad$ ROE - Net profit after interest and tax / Shareholders funds * 100

According to the hypotheses developed, this study constructs regression model for carrying out empirical analysis. The following regression model has been developed to analyze the relationship between ownership structure and financial performance.

$$
\mathrm{ROE}=\beta_{0}+\beta_{1} \mathrm{OC}+\beta_{2} \mathrm{IO}+\beta_{3} \mathrm{FO}+\epsilon
$$

Where,

$\begin{array}{ll}\beta_{0,}, \beta_{1}, \beta_{2}, \beta_{3}-\text { Regression co-efficient } \\ \text { ROE - } & \text { Return on equity } \\ \text { OC - } & \text { Ownership concentration } \\ \text { IO - } & \text { Institutional ownership } \\ \text { FO - } & \text { Foreign ownership } \\ \epsilon \quad- & \text { Error term }\end{array}$

\section{Data Analysis and Discussion}

\subsection{Correlation Analysis}

Table 1 presents the Pearson correlation coefficients between ownership structure and financial performance (ROE). The SPSS output table shows that correlation coefficient between ownership concentration and ROE is $.345^{* *}$ which is significant at 0.01 levels, representing there is a significant positive correlation between ownership concentration and ROE. Because, large shareholders have economic incentives and ability to limited management and seek their own interests which can be more effectively monitor the behavior 
of managers, help to enhance the effectiveness of taking over market optimization and reducing manager's agency costs. This ultimately increases financial performance of the firms. At the same time institutional ownership has no significant correlation with ROE at 0.05 significant levels.

The correlation coefficient between foreign ownership and ROE is $.718^{* *}$ which is significant at 0.01 levels, representing there is a significant positive correlation between foreign ownership and ROE. There are couple reasons why foreign ownership structure increases the financial performance. One reason is that ability to monitor or give incentives for managers leading manage a firm more seriously and avoiding initiatives reducing the corporate values. Another one is that transferring new technologies by foreign firms generating savings on operating expenses.

Table 1. Correlation matrix

\begin{tabular}{lcccc}
\hline & $\begin{array}{c}\text { Ownership } \\
\text { concentration }\end{array}$ & $\begin{array}{c}\text { Institutional } \\
\text { ownership }\end{array}$ & $\begin{array}{c}\text { Foreign } \\
\text { ownership }\end{array}$ & ROE \\
\hline $\begin{array}{l}\text { Ownership } \\
\text { concentration }\end{array}$ & 1 & & & \\
\hline Institutionalo & $.640^{* *}$ & 1 & & \\
wnership & .000 & & & \\
\hline Foreign & $.378^{* *}$ & .058 & 1 & \\
ownership & .007 & .690 & & 1 \\
\hline ROE & $.345^{* *}$ & .233 & $.718^{* *}$ & .000 \\
\hline
\end{tabular}

* Correlation is significant at the 0.05 level (2-tailed)

** Correlation is significant at the 0.01 level (2-tailed)

5.2 Multiple Regression Analysis

Table 2. Coefficients for predictors of financial performance

\begin{tabular}{lrrrr}
\hline \multicolumn{1}{c}{ Model } & Beta & $\begin{array}{c}\text { Standard } \\
\text { Error }\end{array}$ & t value & Significant \\
\hline Constant & -.077 & .970 & -.079 & .937 \\
\hline Ownership concentration & -.416 & .545 & -.764 & .449 \\
\hline Institutional ownership & .477 & .278 & 1.717 & .093 \\
\hline Foreign ownership & 1.053 & .153 & 6.871 & .000 \\
\hline $\mathrm{R}^{2}=0.593$ & & & & \\
\hline
\end{tabular}

Dependent Variable: ROE 


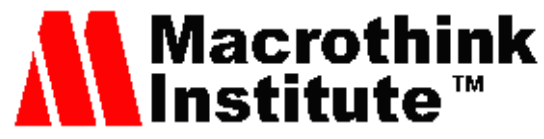

International Journal of Accounting and Financial Reporting

The Table 2 presents the multiple regression summaries. In this model the specification of three variables (ownership concentration, institutional ownership and foreign ownership) revealed the ability to predict the ROE. Respective $\mathrm{R}^{2}$ value of 0.593 denotes that $59.3 \%$ of the observed variability in ROE can be explained by the differences in variables namely ownership concentration, institutional ownership and foreign ownership. The remaining 40.7 $\%$ is not explained which means that the remaining $40.7 \%$ of the variance in ROE is related to other variables not depicted in this model.

Further, this model reveals that the coefficient for two variables such as ownership concentration and institutional ownership are not significant and t values for these variables are insignificant at 0.05 levels. It means that these variables are not contributing to affect the financial performance (ROE). But foreign ownership has a significant impact on ROE. Because $t$ value for the foreign ownership is less than 0.05 significant levels. It shows that foreign investors may monitor the management of companies more closely and hence improve the company performance.

\section{Conclusion and Recommendation}

Pearson correlation analysis shows that significant positive correlation between ownership concentration and financial performance (ROE) which verify first hypothesis and it is supported. This is corroborated by the findings of other works such as Shleifer and Vishny (1997) and Mang'unyi (2011). Further correlation analysis shows that institutional ownership is not correlated with financial performance. So, second hypothesis is not supported. It also displays that foreign ownership has a significant correlation with financial performance. Therefore third hypothesis is supported and this finding is collaborated with previous findings of Douma, George and Kabir (2006) and Ongore (2011).

Based on multiple regression analysis ownership concentration and institutional ownership have no significant impact on financial performance. So, fourth and fifth hypotheses are not supported. Further Table 2 shows that foreign ownership has a significant impact on financial performance. So, sixth hypothesis is supported.

In practical perspectives, this study provides evidence to policy makers that government's proposal to increase foreign stake in listed firm in Sri Lanka because the increase in foreign states may improve financial performance as a linear relationship exist. Moreover, the results of this study provide evidence that investors may make appropriate investment decisions to invest in the companies linked with foreign ownership.

The theoretical implication of this study is that agency problem can be reduced in companies with foreign ownership and also agency cost eliminates in companies with ownership concentration. Ownership concentration result in better monitoring of the management which makes ownership an important element in corporate governance and enhance the financial performance. 


\section{References}

Abu Haija, A. A., \& Alrabba, H. M. (2017). Relationship between ownership structure and financial performance. Corporate Ownership \& Control, 14(3-2), 393-398.

Bauguess, S., Moeller, S., Schlingemann, F., \& Zutter, C. (2009). Ownership structure and target returns. Journal of Corporate Finance, 15(1), 48-65.

Chen, L. (2012). The Effect of Ownership Structure on Firm Performance: Evidence from Non-financial Listed Companies in Scandinavia. Aarhus School of Business. Aarhus University.

Clay, D. G. (2001). Institutional Ownership, CEO incentives, and firm value. University of Chicago.

Demsetz, H., \& Lehn, K. (1985). The Structure of Corporate Ownership: Causes and Consequences. The Journal of Political Economy, 93(6), 1155.

Demsetz, H., \& Villalonga, B. (2001). Ownership structure and corporate performance. Journal of Corporate Finance, 7, 209-233.

Douma, S., George, R., \& Kabir, R. (2006). Foreign and Domestic Ownership, Business Groups, and Firm Performance: Evidence from a Large Emerging Market. Strategic Management Journal, 27(7), 637-57.

Earnhart. D., \& Lizal, L. (2006). Effects of ownership and financial performance on corporate environmental performance. Journal of Comparative Economics.

Fama, E.F., \& Jensen, M.C. (1983). Separation of Ownership and Control. The Journal of Law \& Economics, 26(2), 301-325.

Fauzi, H. (2007). Corporate Social Responsibility and Financial Performance: Empirical Evidence from American Companies. Globsyn Management Journal, Revised Edition.

Gomez, M.L., Nunez-Nickel, M., \& Gutierrez, I. (2001). The role of family ties in agency contracts. Academy of Management Journal, 44(1), 81-95.

Gurbuz, A. O., \& Aybars, A. (2011). The Impact of Foreign Ownership on Firm Performance, Evidence from an Emerging Market: Turkey. American Journal of Economics and Business Administration, 2(4), 350-359.

Gürbüz, A. O., Aybars, A., \& Kutlu, Ö. (2010). Corporate Governance and Financial Performance with a Perspective on Institutional Ownership: Empirical Evidence from Turkey. Journal of Applied Management Accounting Research, 8(2).

Herdjiono, \& Sari. (2017). The Effect of Corporate Governance on the Performance of a Company. Some Empirical Findings from Indonesia. Journal of Management and Business Administration, Central Europe, 25(1).

Hindley, B. (1970). Separation of ownership and control in the modern corporation. Journal of Law and Economics, 13(1), 185. 


\section{MlMacrothink}

International Journal of Accounting and Financial Reporting

ISSN 2162-3082

2017, Vol. 7, No. 2

Huang, R. D., \& Shiu, C.-Y. (2009). Local effects of foreign ownership in an emerging financial market: evidence from qualified foreign institutional investors in Taiwan. Financial Management, 38(3), 567-602.

Jensen, M. C., \& Meckling, W. H. (1976). Theory of the firm: Managerial behavior, agency costs and ownership structure. Journal of Financial Economics, 3(4), 305-360.

Joh, S. (2002). Control, Ownership and Firm Performance: The Case of Korea. Working Paper, Corea Development Institute.

Khanna, T., \& Palepu, K. (2000). Is group affiliation Profitable in emerging markets? An analysis of diversified Indian business groups. Journal of Finance, 55(2), 867-891.

Lee, S. (2008). Ownership structure and financial performance: Evidence from panel data of South Korea. Corporate ownership and Control, 6(2).

Loderer, C., \& Martin, K. (1997).Executive Stock Ownership and Performance Tracking Faint Traces. Journal of Financial Economics, 45(2), 595-612.

Mang'unyi, E. (2011). Ownership Structure and Corporate Governance and Its Effects on Performance: A Case of Selected Banks in Kenya. International Journal of Business Administration, 2(3), 2-17.

Miller, D., Le Breton-Miller, I., Lester, R.H., \& Cannella, A.A. (2007). Are family firms really superior performers? Journal of Corporate Finance, 13(5), 829-858.

Najjar, J. H. (2015). An Empirical Study of Corporate Companies listed at Palestine Exchange. International Journal of Novel Research in Marketing Management and Economics, 2(2), 135-148.

Ødegaard, B.A., \& Bøhren, Ø. (2003). Governance and Performance Revisited. SSRN Working Paper Series - LA English.

Ongore, V.O. (2011). The relationship between ownership structure and firm performance: An empirical analysis of listed companies in Kenya. African Journal of Business Management, 5(6), 2120-8.

Pivovarsky, A. (2003). Ownership Concentration and Performance in Ukraine's Privatized Enterprises. IMF Staff Papers, 50(1), 10-42.

Sanchez-Ballesta, J. P., \& Garcia-Meca, E. (2007).Ownership structure, discretionary accruals and the informativeness of earnings. Corporate Governance: An International Review, 15(4), 677-691.

Sanda, A., Mikailu, A., \& Garba, T. (2005).Corporate governance mechanism and firm financial performance in Nigeria. AERC research paper 149, Nairobi: African Economic Research Consortium. 


\section{Macrothink}

International Journal of Accounting and Financial Reporting

ISSN 2162-3082 2017, Vol. 7, No. 2

Shan, Y. G., \& McIver, R. P. (2011). Corporate governance mechanisms and financial performance in China: panel data evidence on listed non-financial companies. Asia Pacific Business Review, 17(3), 301-324.

Shleifer, A., \& Vishny, R.W. (1986).Large Shareholders and Corporate Control. The Journal of Political Economy, 94(3), 461.

Shleifer, A., \& Vishny, R. W. (1997).A survey of corporate governance. The Journal of Finance, 52(2), 737-783.

Soufeljil, M., Sghaier, A., Kheireddine, H., \& Mighri, Z. (2016).Ownership Structure and Corporate Performance: The Case of Listed Tunisian Firms. Journal of Business \& Financial Affairs, 5, 222.

Tsegba, I. N., \& Ezi-herbert, W. (2011). The relationship between ownership structure and firm performance: Evidence from Nigerian. African Journal of Accounting, Economics, Finance and Banking Research, 7(7), 51-63.

Warrad, L., Almahamid, S. M., Slihat, N., \& Alnimer, M. (2013). The Relationship Between Ownership Concentration and Company Performance, A Case of Jordanian Non-Financial Listed Companies. Interdisciplinary Journal of Contemporary Research in Business, 4(9), 17-38.

Welch, E. (2003). The Relation between Ownership Structure and Performance in Listed Australian Companies. Australian Journal of Management, 28(3), 287-305.

Xu, X.N., \& Wang, Y. (1999).Ownership structure and corporate governance in Chinese stock companies. China Economic Review, 10, 75-98.

\section{Copyright Disclaimer}

Copyright for this article is retained by the author(s), with first publication rights granted to the journal.

This is an open-access article distributed under the terms and conditions of the Creative Commons Attribution license (http://creativecommons.org/licenses/by/4.0/) 